Conference wins the support of

\section{prominent politicians}

[LONDON] More than 100 ministers of science or education are expected to address the plenary session of the World Conference on Science in Budapest at the end of June, according to Unesco officials.

Their presence at what some officials say might be considered as "the first real world conference on science" is being taken as a sign that many countries are prepared to make a political endorsement of the importance of the conference. They are also seen as supporting its primary theme - the need to establish a 'new social contract for science' appropriate to the twenty-first century.

"The idea is that, during the plenary session, governments will make a commitment to science," said Howard Moore, the secretary of the conference. "We hope this will ensure a real increase in scientific effort."

One participant will be the German minister of science, Edelgard Bulmahn, who is said to be keen to highlight the situation of women in science, a topic on which she has obtained a commitment to greater activity by Europe's research ministers.

Another prominent minister who will be speaking is Akito Arima, education and research minister of Japan. Neal Lane, President Bill Clinton's science adviser, will address the opening plenary session on "the responsibility of the scientist to digest the growing volume of knowledge, to share knowledge with society, and to understand where this new knowledge will lead".

One science minister who will be missing is Britain's David Sainsbury. The British paper will probably be delivered by George Foulkes, parliamentary under-secretary of state in the Department for International Development. Full text: http://helix.nature.com/wcs/a40.htm

\section{Science academies 'should encourage ethics debates'}

[LONDON] Every academy of science throughout the world should set up a panel of members to study and monitor ethical problems arising from modern science, according to medical physicist Sir Joseph Rotblat, the Nobel peace prizewinner in 1995.

He also suggests that all scientists should be encouraged to sign an oath on graduation pledging to work for the good of humanity. Rotblat is a founder and was for many years president of the Pugwash conferences on science and world affairs, an organization of researchers dedicated to the cause of peace.

"Ethical problems should become part of the terms of reference of all academies of science," Rotblat told a meeting in London last week. He outlined some of the ideas that he intends to present during a keynote speech on science and human values on the first day of the World Conference on Science.

Acknowledging that many academies are already engaged in such debates, Rotblat suggested that this role should become "normative" rather than optional. The job of scientists nominated to sit on such ethical committees, he said, "will be to try to work out

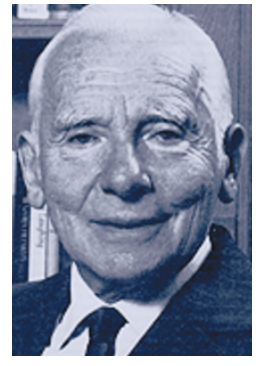

Rotblat: 'work for good of humanity'. jects, for example in genetic engineering."

The code of conduct that Rotblat suggests should be followed by scientists would be similar to the Hippocratic oath taken by doctors. "This makes them aware that their prime duty is to the patient," he said. "Now that science can affect the fate of so many humans, it is important for scientists to be aware of the situation."

In his talk, Rotblat will address "the education of scientists as responsible citizens and contributors to the culture of peace". Full text: http://helix.nature.com/wcs/a42.htm

\section{Australian nominated for Unesco top job}

[SYDNEY] Australia's conservative Coalition government announced on Monday (7 June) that it is nominating one of its main political opponents, Gareth Evans, to become director general of Unesco when the post becomes vacant later this year. The surprise move pitches Evans against a lengthy list of nominations, including that from Japan, Koichiro Matsuura (see Nature 398, 554; 1999).
Evans, aged 54, has wide international experience. He brokered the Cambodian peace settlement, and was once touted as a potential secretary general of the United Nations. He served as foreign minister in Australia's Labor government until 1996 and was deputy leader of the opposition until the October 1998 election, after which he did not stand for office.

\title{
Ministers set to back promotion of science in Muslim countries
}

[LONDON] Twenty science ministers from Muslim countries are expected to give their blessing at the World Conference on Science to plans for a major exhibition on science, technology and medicine in Islam.

The exhibition is to be organized jointly by Unesco and its counterpart organization, the Islamic Scientific, Educational, and Cultural Organization, based in Morocco.

The exhibition will move to a new country every six months. It will begin in Granada, Spain, from where it is expected to follow a route that will take in the Middle
East, North Africa, Sub-Saharan Africa, Asia, Europe and North America.

The ministers will also meet at the conference to agree a strategy document on the future of science in the Muslim world.

Atta-ur-Rahman, coordinator-general of Comstech, the ministerial standing committee for scientific and technological cooperation of the Organization of Islamic Countries, says three critical issues that many developing countries need to solve are skills shortages, excessive bureaucracy, and poor salaries for scientists.

^๑ 1999 Macmillan Magazines Ltd
Rahman, who was announced last week as the recipient of this year's Unesco science prize, believes that governments should pick out "the brightest students from high schools and have them trained in selected disciplines at the best universities and research centres in the Western world".

Rahman says he believes that the scientific progress of the developing world "will lead to a decrease in international tensions, and lead to a more harmonious and healthier global environment". Full text: http://helix.nature.com/wcs/a41.html 